\title{
30 YEARS OF THE MINERALOCORTICOID RECEPTOR Evolution of the mineralocorticoid receptor: sequence, structure and function
}

\section{Michael E Baker ${ }^{1}$ and Yoshinao Katsu²}

1Division of Nephrology-Hypertension, Department of Medicine, University of California, San Diego, CA, USA ${ }^{2}$ Graduate School of Life Science, Hokkaido University, Sapporo, Japan
Correspondence should be addressed to $\mathrm{M} \mathrm{E}$ Baker or Y Katsu Email

mbaker@ucsd.edu or ykatsu@sci.hokudai.ac.jp

\begin{abstract}
The mineralocorticoid receptor (MR) is descended from a corticoid receptor (CR), which has descendants in lamprey and hagfish, cyclostomes (jawless fish), a taxon that evolved at the base of the vertebrate line. A distinct MR and GR first appear in cartilaginous fishes (Chondrichthyes), such as sharks, skates, rays and chimeras. Skate MR has a strong response to corticosteroids that are mineralocorticoids and glucocorticoids in humans. The half-maximal responses (EC50s) for skate MR for the mineralocorticoids aldosterone and 11-deoxycorticosterone are $0.07 \mathrm{nM}$ and $0.03 \mathrm{nM}$, respectively. EC50s for the glucocorticoids cortisol and corticosterone are $1 \mathrm{nM}$ and $0.09 \mathrm{nM}$, respectively. The physiological mineralocorticoid in ray-finned fish, which do not synthesize aldosterone, is not fully understood because several 3-ketosteroids, including cortisol, 11-deoxycortisol, corticosterone, 11-deoxycorticosterone and progesterone are transcriptional activators of fish MR. Further divergence of the MR and GR in terrestrial vertebrates, which synthesize aldosterone, led to emergence of aldosterone as a selective ligand for the MR. Here, we combine sequence analysis of the CR and vertebrate MRs and GRs, analysis of crystal structures of human MR and GR and data on transcriptional activation by 3-ketosteroids of wild-type and mutant MRs and GRs to investigate the evolution of selectivity for 3-ketosteroids by the MR in terrestrial vertebrates and ray-finned fish, as well as the basis for binding of some glucocorticoids by human MR and other vertebrate MRs.
\end{abstract}

\section{Key Words}

- corticosteroid receptor evolution

- mineralocorticoid receptor evolution

- glucocorticoid receptor evolution

- lamprey

- cartilaginous fishes

\section{Introduction}

In this special issue of JOE, we celebrate the thirtieth anniversary of cloning of the mineralocorticoid receptor (MR) in the Evans laboratory at the Salk Institute (Arriza et al. 1987). This was an impressive achievement. Indeed, it was not an easy task, as the MR was the last cloned receptor from the adrenal and sex steroid receptor family, which also includes the glucocorticoid receptor $(\mathrm{GR})$, progesterone receptor (PR), androgen receptor (AR) and estrogen receptor (ER) (Evans 1988, Markov et al. 2009, Baker et al. 2015). The MR and other steroid receptors belong to the nuclear receptor family, a diverse group of transcription factors that arose in multicellular animals, which have key roles in the physiology of humans and other vertebrates (Markov et al. 2009, Bridgham et al. 2010, Huang et al. 2010, Baker et al. 2013). A 3-ketosteroid receptor (SR) ancestor of the MR, GR, PR and AR first

\footnotetext{
This paper is part of a thematic review section on 30 Years of the Mineralocorticoid Receptor. The guest editors for this section were

John Funder and Maria,Christina ZennarQioscientifica.com at 04/26/2023 11:24:11AM 


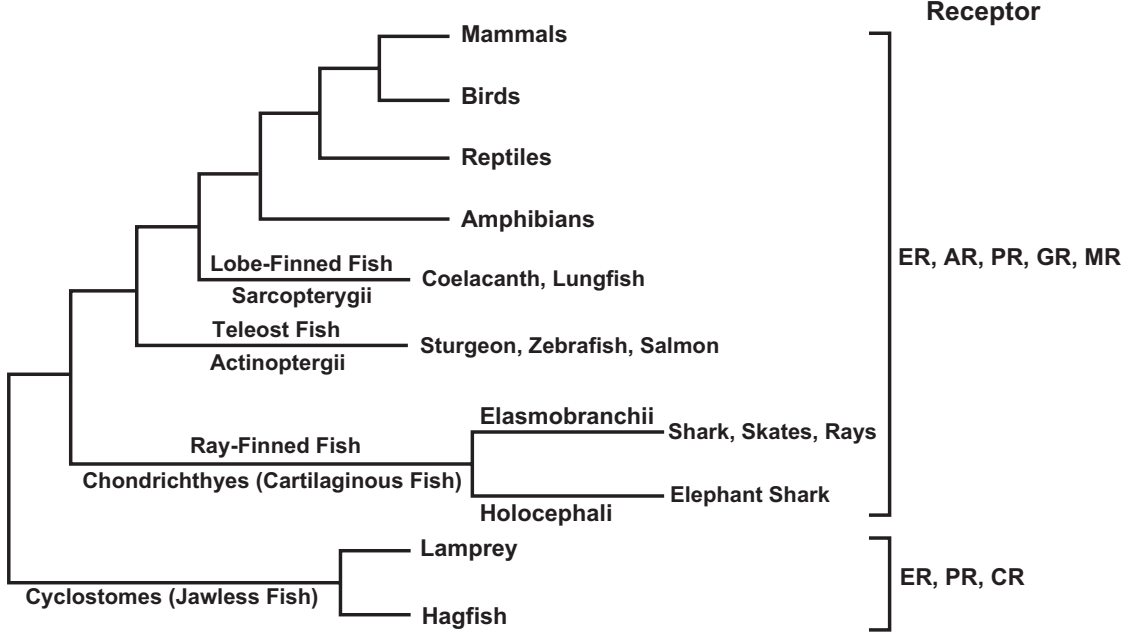

\section{Figure 1}

MR, GR, PR, AR and ER in vertebrates. The ER, CR and $P R$ are found in lampreys and hagfish, which are jawless fishes (cyclostomes) that evolved at the base of the vertebrate line. A separate MR and GR are found in cartilaginous fish (Chondrichthyes), which are divided into the subclass Elasmobranchii containing sharks, skates and rays and the subclass Holocephali (chimeras) containing elephant sharks and which together are basal jawed vertebrates. These basal jawed vertebrates, which contain cartilage instead of bone, are forerunners of bony fishes, which are divided into the subclass Actinopterygii (ray-finned fish) containing, for example, sturgeon, zebrafish and salmon, and the subclass Sarcopterygii (lobe-finned fish ) containing coelacanths and lungfish, which are forerunners of tetrapods (land vertebrates). The AR first appears in cartilaginous fishes. appears in amphioxus, a close ancestor of vertebrates (Bridgham et al. 2008, Paris et al. 2008, Markov et al. 2009, Katsu et al. 2010, Baker et al. 2015).

The availability of recombinant human MR facilitated the cloning of MRs from a wide variety of vertebrates and an analysis of the evolution of the MR. These MR sequences and those of the GR confirmed the original observation of kinship between the MR and GR (Arriza et al. 1987, Evans 1988, Bridgham et al. 2006, Baker et al. 2007, Kassahn et al. 2011). The MR and GR are descended from the corticoid receptor (CR) (Thornton 2001, Bridgham et al. 2006, Baker et al. 2007, Kassahn et al. 2011, Baker et al. 2015). Descendants of the ancestral CR are found in lampreys and hagfish, which are cyclostomes (jawless fish), a taxon that evolved at the base of the vertebrate line (Fig. 1) (Osorio \& Retaux 2008, Sauka-Spengler \& Bronner-Fraser 2008). A distinct MR first appears in cartilaginous fishes (Chondrichthyes), which consist of two subclasses Elasmobranchii containing sharks, skates and rays, and Holocephali containing chimeras, such as the elephant shark (Bridgham et al. 2006, Carroll et al. 2008, Baker et al. 2015).

Studies with recombinant human MR yielded some unexpected findings. (Arriza et al. 1987) Aldosterone (Aldo), cortisol (F), 11-deoxycortisol (S), corticosterone (B) and 11-deoxycorticosterone (DOC) (Fig. 2) had similar equilibrium binding constants (Kds) for human MR (Arriza et al. 1987, Rupprecht et al. 1993b). Similar findings were reported for rat MR (Krozowski \& Funder 1983, Myles \& Funder 1994) and guinea pig MR (Myles \& Funder 1994). Progesterone (Prog) also has high affinity for human MR (Arriza et al. 1987, Rupprecht et al. 1993b, Sugimoto et al. 2016), rat MR (Myles \& Funder 1996) and guinea pig MR (Myles \& Funder 1996). This indicated that the steroid-binding site on the human MR was not selective for physiological mineralocorticoids (Aldo, DOC) over glucocorticoids (F, B, S) and Prog.

The similar affinity of F, B and Aldo for the MR raised the question of how Aldo could occupy human MR in the presence of $\mathrm{F}$ and mouse and rat MR in the presence of $\mathrm{B}$, which have from 100 to 1000 fold higher concentrations in t serum than that of Aldo. Human MR should be occupied by $\mathrm{F}$ and rat and mouse MR by $\mathrm{B}$. Selective activation by Aldo of the MR in the presence of either F or B arises from a novel enzymatic mechanism involving expression of $11 \beta$-hydroxysteroid dehydrogenase-type 2 (11ßHSD2) in epithelia containing the MR. This enzyme metabolizes the $11 \beta-\mathrm{OH}$ of $\mathrm{F}$ and $\mathrm{B}$ to a ketone, yielding cortisone and 11-dehydrocorticosterone, respectively, two inactive steroids (Edwards et al. 1988, Funder et al. 1988, Draper \& Stewart 2005, Baker 2010, Odermatt \& Kratschmar 2012, Chapman et al. 2013). Aldo is inert to 11ßHSD2 and can occupy the kidney and colon MRs in the presence of $11 \beta$ HSD2, activating the MR. However, DOC, S and Prog lack an $11 \beta-\mathrm{OH}$, which allows these steroids to compete with Aldo for the MR.

Specificity of human MR for Aldo compared to other corticosteroids also comes from Aldo's strong transcriptional activation of the MR. Indeed, a follow-up paper (Arriza et al. 1988) showed that the half-maximal response (EC50) of Aldo for human MR was over 100X lower than that of F. Subsequent reports extended the stronger response of the human MR to Aldo compared to other corticosteroids (Rupprecht et al. 1993b, Lombes et al. 1994, Hellal-Levy et al. 1999, Mani et al. 2016, Sugimoto et al. 2016). The basis for the stronger response to Aldo is not understood. Among the possible contributors to the stronger transcriptional activation of the MR by Aldo

Published by Bioscientifica Ltd 


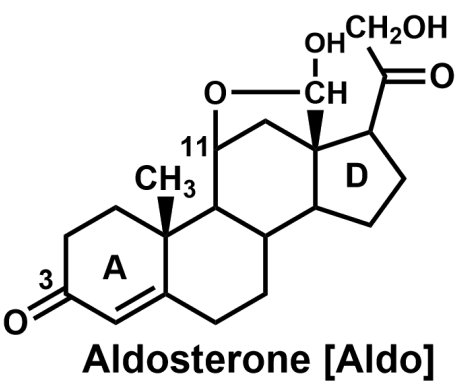<smiles>CC(=O)[C@H]1CCC2C1[C@@H](O)C[C@]1(C)C2CCC2=CC(=O)CC[C@@]21C</smiles>

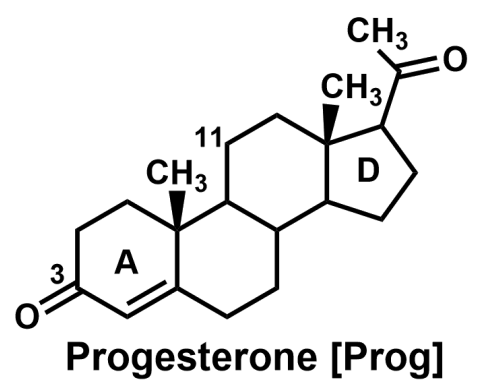<smiles>CC(=O)[C@]1(O)CCC2C1[C@@H](O)C[C@]1(C)C2CCC2=CC(=O)CC[C@@]21C</smiles>

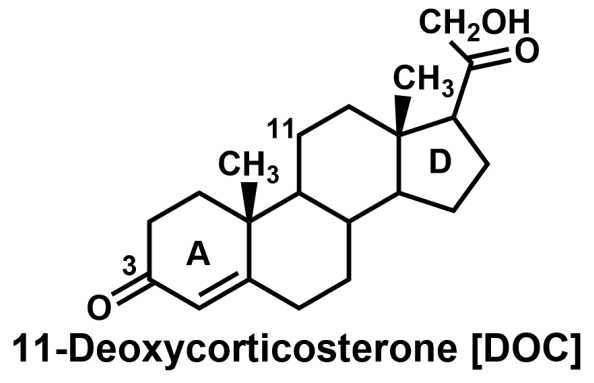

Figure 2

Structures of mineralocorticoids and glucocorticoids. Aldosterone [Aldo] and 11-deoxycorticosterone [DOC] are the main physiological mineralocorticoids in vertebrates. Cortisol $[\mathrm{F}]$ and corticosterone $[\mathrm{B}]$ are the main physiological glucocorticoids in vertebrates. 11-deoxycortisol [S] has activity as mineralocorticoid and glucocorticoid in lamprey CR (Baker 2011). Progesterone [Prog] is an antagonist for human MR (Rupprecht et al. 1993b, Geller 2000) and an agonist for fish MRs (Sturm et al. 2005, Pippal et al. 2011, Sugimoto et al. 2016) than by other corticosteroids are differences in cell types, which have been shown to alter the response of the MR to Aldo and F (Lim-Tio et al. 1997). The longer off-time Aldo from the MR has been proposed to be important in Aldo activation of human MR (Hellal-Levy et al. 1999). Lastly, the stronger transcriptional activity of Aldo compared to F and other corticosteroids may be due to Aldo's stronger stabilization of an interaction between the N-terminal $\mathrm{A} / \mathrm{B}$ domain and the ligand-binding domain (Rogerson \& Fuller 2003, Pippal et al. 2009, 2011). In this regard, allosteric interactions between the A/B domain and the ligand-binding domain also are important in differences among corticosteroids in transcriptional activation of the GR (Pearce \& Yamamoto 1993, Rupprecht et al. 1993a, Oka et al. 2015, Katsu et al. 2016). Interestingly, Prog is an antagonist for human MR (Kagawa 1958, Wambach \& Higgins 1978, Funder \& Adam 1981, Rupprecht et al. 1993b, Geller et al. 2000, Sugimoto et al. 2016).

Important in understanding $\mathrm{MR}$ evolution is the pathway for the synthesis of corticosteroids that are ligands for the MR (Fig. 3). Progressive modification of
Prog yields steroids with substituents that are ligands for either the MR and GR or both. The position of each steroid in this pathway appears to coincide with the evolution of steroids in vertebrates as physiological activators of the CR, MR and GR. For example, Aldo, which is at the end of one synthetic pathway, is not present in either lamprey or hagfish serum (Bridgham et al. 2006). Potential activators of the CR are S, DOC and Prog, which have been found in Atlantic sea lamprey serum (Close et al. 2010, Roberts et al. 2014, Wang et al. 2016). These steroids are at the beginning of the pathway. $\mathrm{S}$ has mineralocorticoid activity in lamprey (Close et al. 2010); the roles of DOC, which is a mineralocorticoid in mammals (Lam et al. 2006, Hawkins et al. 2012), and of Prog are not known.

Chondrichthyes contain $\mathrm{B}$ and a novel derivative $1 \alpha-\mathrm{OH}-\mathrm{B}$, which has not been found in other vertebrates. $\mathrm{F}$ and $\mathrm{B}$, but not Aldo, are found in ray-finned fish (Jiang et al. 1998, Sakamoto et al. 2011). Aldo first appears in lungfish (Joss et al. 1994, Rossier et al. 2015), which also secrete F and B. Lungfish are the closest extant forerunners of tetrapods (Woolston 2013). 
<smiles>CCC(=O)[C@H]1CCC2C3CCC4=CC(=O)CC[C@]4(C)[C@H]3CC[C@@]21C</smiles>

Progesterone (Prog)<smiles>C[C+]C=CC</smiles>

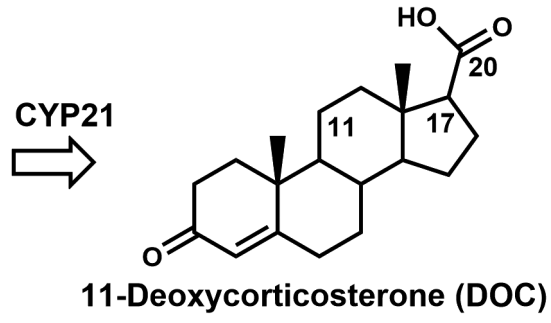

11-Deoxycorticosterone (DOC)

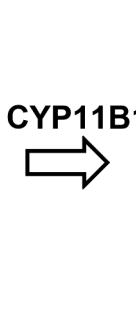

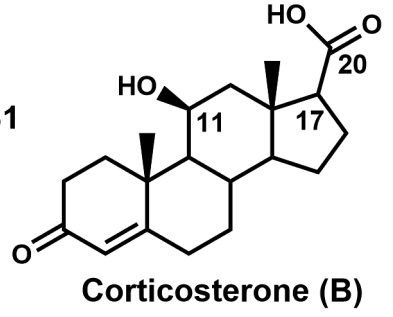<smiles>C[C@H](CC1CCC1)C(C)(C)C</smiles>
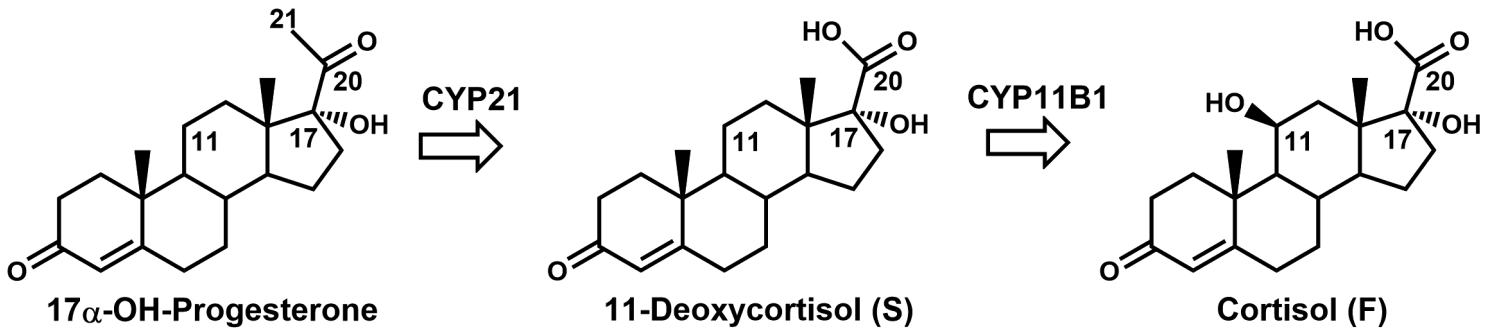

Figure 3

Pathway for the synthesis of aldosterone from progesterone and cortisol from $17 \alpha-\mathrm{OH}$-Progesterone. Progesterone is hydroxylated at $\mathrm{C} 21$ to form 11-deoxycorticosterone, which is hydroxylated at C11 to form corticosterone. Hydroxylated corticosterone at C18 followed by oxidation of the C18 hydroxyl forms aldosterone. In a second pathway, progesterone is hydroxylated at C17 and then hydroxylated at C21 to form 11-deoxycortisol, which is hydroxylated at C11 to form cortisol (Baker 2011, Rossier et al. 2015).

Interestingly, Aldo has low EC50s for the MR in vertebrates that do not synthesize Aldo. The EC50 of Aldo for hagfish CR is $0.4 \mathrm{nM}$ (Bridgham et al. 2006). The EC50s of Aldo, DOC and B for skate MR are $0.07 \mathrm{nM}, 0.03 \mathrm{nM}$ and $0.09 \mathrm{nM}$, respectively (Carroll et al. 2008). 11ßHSD2 first appears in Chondrichthyes (Baker et al. 2015, Rossier et al. 2015), in which 11ßHSD2 may regulate access of $\mathrm{B}$ to the MR. Although Aldo is not found in ray-finned fish, Aldo is a strong transcriptional activator of fish MR (Greenwood et al. 2003, Sturm et al. 2005, Stolte et al. 2008, Pippal et al. 2011, Sugimoto et al. 2016). Indeed, the physiological mineralocorticoid in ray-finned fish is not fully understood because several 3-ketosteroids, including F, DOC, B, S and Prog are transcriptional activators of the MR (Greenwood et al. 2003, Sturm et al. 2005, Stolte et al. 2008, Pippal et al. 2011, Sugimoto et al. 2016), and one or more of these steroids could be a physiological mineralocorticoid.

Thus, during the evolution of the MR in cartilaginous fishes, ray-finned fishes and terrestrial vertebrates, there have been changes in the EC50 of the MR for 3-ketosteroids (Sturm et al. 2005, Carroll et al. 2008, Pippal et al. 2011, Sugimoto et al. 2016), as well as the MR's physiological function (Vize \& Smith 2004, Hawkins et al. 2012, Martinerie et al. 2013, Rossier et al. 2015, Jaisser \& Farman 2016, Mifsud \& Reul 2016, Sakamoto et al. 2016). It needs to be noted that transcriptional activation by corticosteroids of fish MRs is studied in mammalian cells, which may provide different responses than in assays using homologous fish cells. To gain a deeper understanding of the evolution of the MR, we have taken advantage of the sequencing, in the last five years, of a cornucopia of genomes from vertebrates at key evolutionary transitions, including lamprey, a jawless fish, elephant shark, a basal jawed fish and coelacanth, which, along with lungfish, belongs to the lobe-finned fish clade, forerunners of terrestrial vertebrates, to investigate regions of conservation and divergence among and between MRs and GRs. We use these sequence analyses, the crystal structures human MR (Bledsoe et al. 2005, 
Fagart et al. 2005, Li et al. 2005, Edman et al. 2015) and GR (Bledsoe et al. 2002, He et al. 2014) and functional studies of human MR mutants (Fagart et al. 1998, Geller et al. 2000, Bledsoe et al. 2005, Li et al. 2005, Shibata et al. 2013, Jimenez-Canino et al. 2016, Mani 2016) to investigate the evolution of selectivity for Aldo and other corticosteroids by the MR in terrestrial vertebrates (Baker et al. 2013) and ray-finned fish (Prunet et al. 2006, Bury \& Sturm 2007, Arterbery et al. 2011, Sugimoto et al. 2016), as well as the basis for binding of some glucocorticoids by human MR and other vertebrate MRs (Li et al. 2005, Mani et al. 2016). Together, these data provide molecular and structural fingerprints for investigating the evolution of selectivity for 3-ketosteroids by the MR in vertebrates.

\section{The MR is a multi-domain transcription factor}

Like other steroid receptors, the MR is composed of several functional domains (Fig. 4). The MR contains an $\mathrm{A} / \mathrm{B}$ domain at the N-terminus (NTD), a DNA-binding domain (DBD) (C domain) near the center, a short hinge domain (D domain) and a steroid-binding domain (LBD) (E domain) at the C-terminus (Arriza et al. 1988, Pascual-Le Tallec \& Lombes 2005, Yang \& Young 2009, Huang et al. 2010, Huyet et al. 2012). The A/B domain contains an activation function 1 [AF1], and the E domain contains an AF2 domain (Li et al. 2005, Pascual-Le Tallec \& Lombes 2005, Huyet et al. 2012, Faresse 2014). Each domain in MR is important for transcriptional responses (Faresse 2014, Fuller et al. 2012).

As shown in Fig. 4, the DBD is highly conserved in vertebrate MRs, while the NTD and hinge domains are poorly conserved. The LBD has intermediate sequence conservation, which makes it useful for phylogenetic analysis of the MR (Bridgham et al. 2008, Baker et al. 2015, Rossier et al. 2015). In addition, the sequence of the LBD in vertebrate MRs is of interest because mutations in the LBD have been correlated with changes in transcriptional activation by Aldo and other steroids (Fagart et al. 1998, Geller et al. 2000, Bledsoe et al. 2005, Fagart et al. 2005, Li et al. 2005, Bridgham et al. 2006, Funder 2013, Shibata et al. 2013, Mani 2016). Thus, a multiple alignment of the LBD of key vertebrate MRs and GRs can be used for a phylogenetic analysis of the MR, as well as to identify
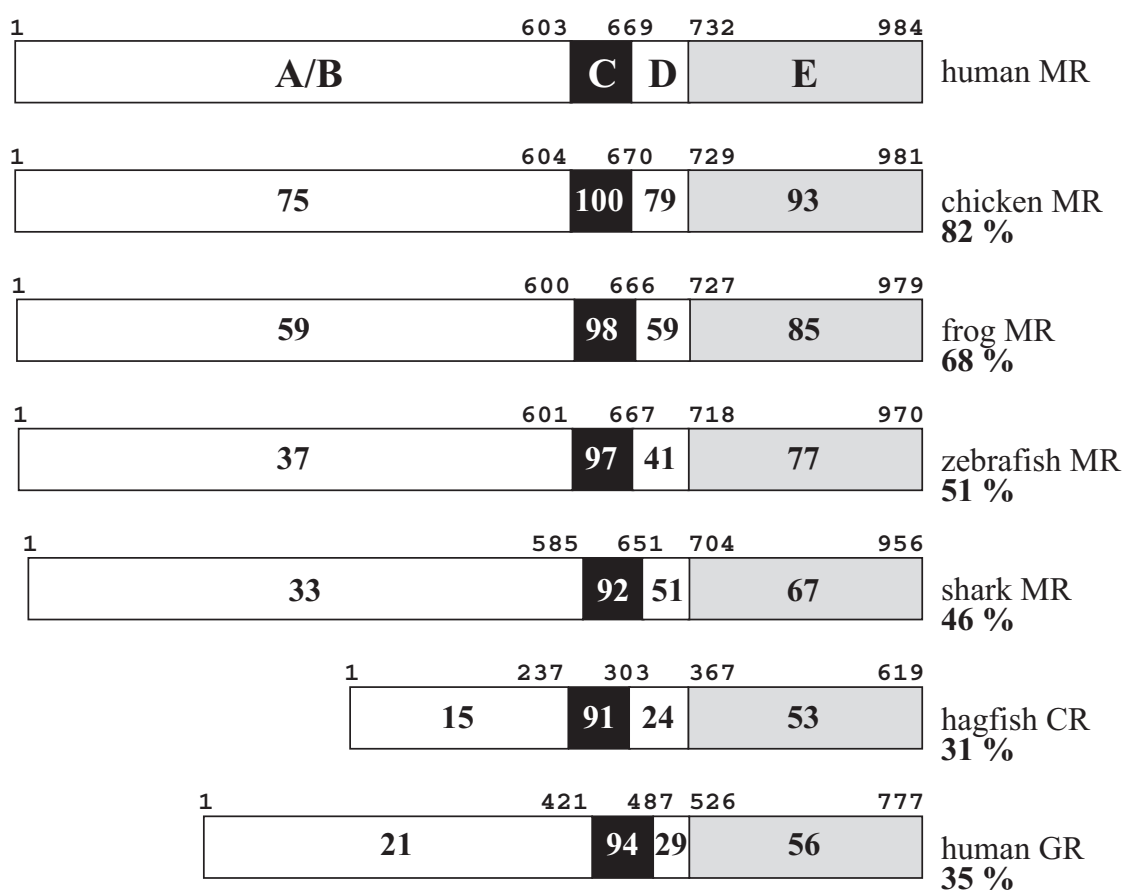

Figure 4

Comparison of domains on MR, GR, PR, AR and $C R$. The A/B domain to $E$ domains are schematically represented with the numbers of amino acid residues and the percentage of amino acid identity between the domains compared to human MR. For example, the entire human MR sequence is $82 \%$ identical to that of chicken $M R$, while domain $\mathrm{E}$ (LBD) on human MR is $93 \%$ identical to that of chicken MR. Accessions are in Supplement Table 1 (see section on supplementary data given at the end of this article). 


human MR
frog MR
coelacanth MR
zebrafish MR
elephant shark MR
human GR
coelacanth GR
elephant shark GR
hagfish CR
lamprey CR
hagfish PR
lamprey PR
human PR
human AR
human MR coelacanth MR zebrafish MR elephant shark MR human GR coelacanth GR elephant shark GR hagfish CR lamprey CR hagfish PR hagiish PR human PR human AR

732 RALTPSPVMVLENIEPEIVYAGYDSSKPDTAENLLSTLNRLAGKQMIQVVKWAKVLPGFKNLPLE 727 P-I-L-AAVI-- 742 PL-A-PVGAF-OA----V------NTQ-

718 PY----VCS---L----V-F----NTQ---TDH--TS--Q-------R-----------RS--I-

704 MHINH-VTT--OV----V---C----V--NTTH---S--

526 PQ---TL-SL--V----VL---

547 PQ---TMISL--A---S-L-S----TI---HCR-MTA--K-G-R-VVAA-----A----RS-H-D

186 SL---AMISI--G---DVI--S---TI---PHR---G--T-G-R---SA-----TI---Q--H-D

367 PVIS-PL-ST-QV---D-IS--F-N-RAM-TTY---S--T-CE--LVFL-----AM---RS-HID

186 PIFS-TLIAI-OA----V-MS---NTRSO-TAYM--S----CD--LVSI-----S----R--HID

405 HS-V--IISI-RF----V----F-NTO-V-TNY---S----CE--IVP------------E-HID

405 LSYS--ILSI-QL----V----F-N-R-M--NY--TS---CCER-LVP----

681 IQ-I-PLINL-MS---DVI---H-NT----SSS--TS--Q-GER-LLS----S-S----R--HID

668 YECQ-IFLN---A---GV-C--H-NNQ--SFAA---S--E-GER-LVH------A----R--HVD

$$
{ }^{\mathrm{H} 1} 810 \text { H3 } 843 \quad 848852
$$

797 DQITLIQYSWMMCLSSFALSWRSYKHTNSQFLYFAPDLVFNEEKMHQSAMYELCQGMHQISLQFVR

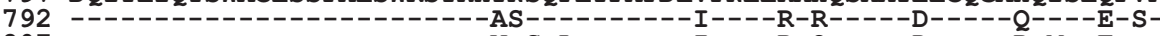
807 783 -

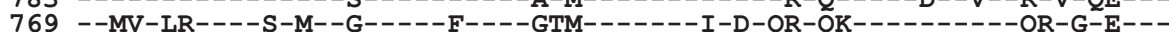
591 --M--L-----F-MA---G----RQSSANL-C-----II--QR-TLPC--DQ-KH-LYV-SELH612 --MV-L-----F-MA-G-G----QQA-GSM-C-----II--QR-QLPY---Q--H-LK-ASE-S251 --MM-L-----S-MV-S-G----QY ---NM-F-----IL--DR-Q--S-----K---S--IE-RN 432 --MV------GIMA--MG----IN--CEL-------I---QR-K-----D--L--RN-GEEMM251 --MV-------G-M---M----FO----KL-------DD-TR-O-----O--VE-R-V-ED-MK 470 --M--------G-MA--MG---H-LV-G-M-------I---QR-Q-------M--Q---KE-S-

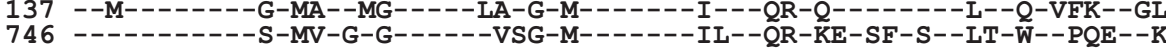
733 --MAV------G-MV--MG---FTNV--RM---------YR--K-R--SQ-VR-RHL-QE-GW $\mathrm{H} 4 \mathrm{H} 5 \mathrm{H} 6 \frac{\mathrm{H} 7}{2}$

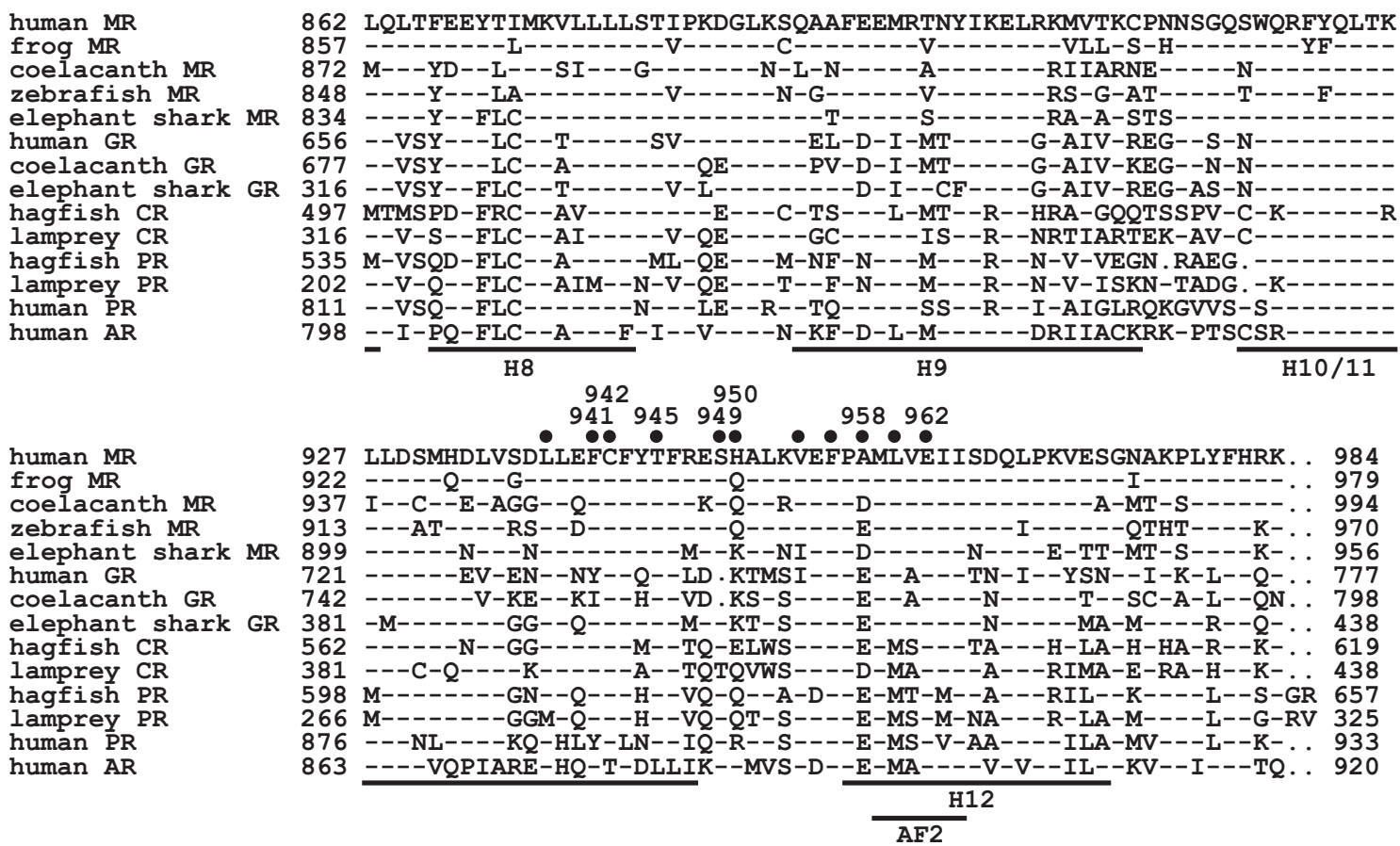

Figure 5

Alignment of the steroid-binding domain on vertebrate MRs, CRs, GRs, PRs and AR. The steroid-binding domains were collected with BLAST searches of GenBank. Clustal W2 was used to construct the multiple alignment (Larkin et al. 2007). The crystal structure of human MR (PDB: 2A3I) (Li et al. 2005) was used to locate $\alpha$-helices. Amino acids that contact Aldo are shown above human MR. The highly conserved Glu-962 is part of AF2, which contacts coactivator proteins. The functions of Ser-949 and His-950 remain to be elucidated.

http://joe.endocrinology-journals.org DOI: 10.1530/JOE-16-0661
() 2017 Society for Endocrinology Printed in Great Britain
Published by Bioscientifica Ltd 
sites that could be important in functional divergence of vertebrate MRs from each other and from the GR.

\section{Evolution of vertebrate MR steroid-binding domain: divergence from its GR paralog}

Figure 5 shows a multiple alignment of the steroidbinding domain on various MRs, GRs, CRs, PRs and AR from vertebrates at key evolutionary transitions. Figure 5 also shows the $\alpha$-helices on the MR as determined by X-ray crystallography (Bledsoe et al. 2005, Fagart et al. 2005, Li et al. 2005, Edman et al. 2015) and amino acids that have been found to be important in either steroid binding or transcriptional activation of the MR or CR (Fagart et al. 1998, Geller et al. 2000, Bledsoe et al. 2005, Hultman et al. 2005, Li et al. 2005, Bridgham et al. 2006,
Shibata et al. 2013, Edman et al. 2015, Jimenez-Canino et al. 2016, Mani et al. 2016) or the GR (Bledsoe et al. 2002, He et al. 2014, Edman et al. 2015, Mani et al. 2016). A striking feature, discussed in more detail below, is the strong conservation of amino acids among the CR, MR, GR, PR and AR, including lamprey PR and CR. Indeed, some amino acids are conserved across vertebrate MRs, GRs and CRs and even in lamprey and hagfish PRs.

We used this multiple alignment to construct an updated phylogeny of the steroid-binding domain on the MR and other 3-ketosteroid receptors (Fig. 6). This phylogeny indicates that the CR and PR evolved from an ancestral 3-ketosteroid receptor through gene duplication and divergence (Thornton 2001, Baker et al. 2015, Rossier et al. 2015); that the MR and GR evolved from an ancestral CR; that the MR is closer than the GR is to the $\mathrm{CR}$, and that the CR ancestor of the MR and GR appears to

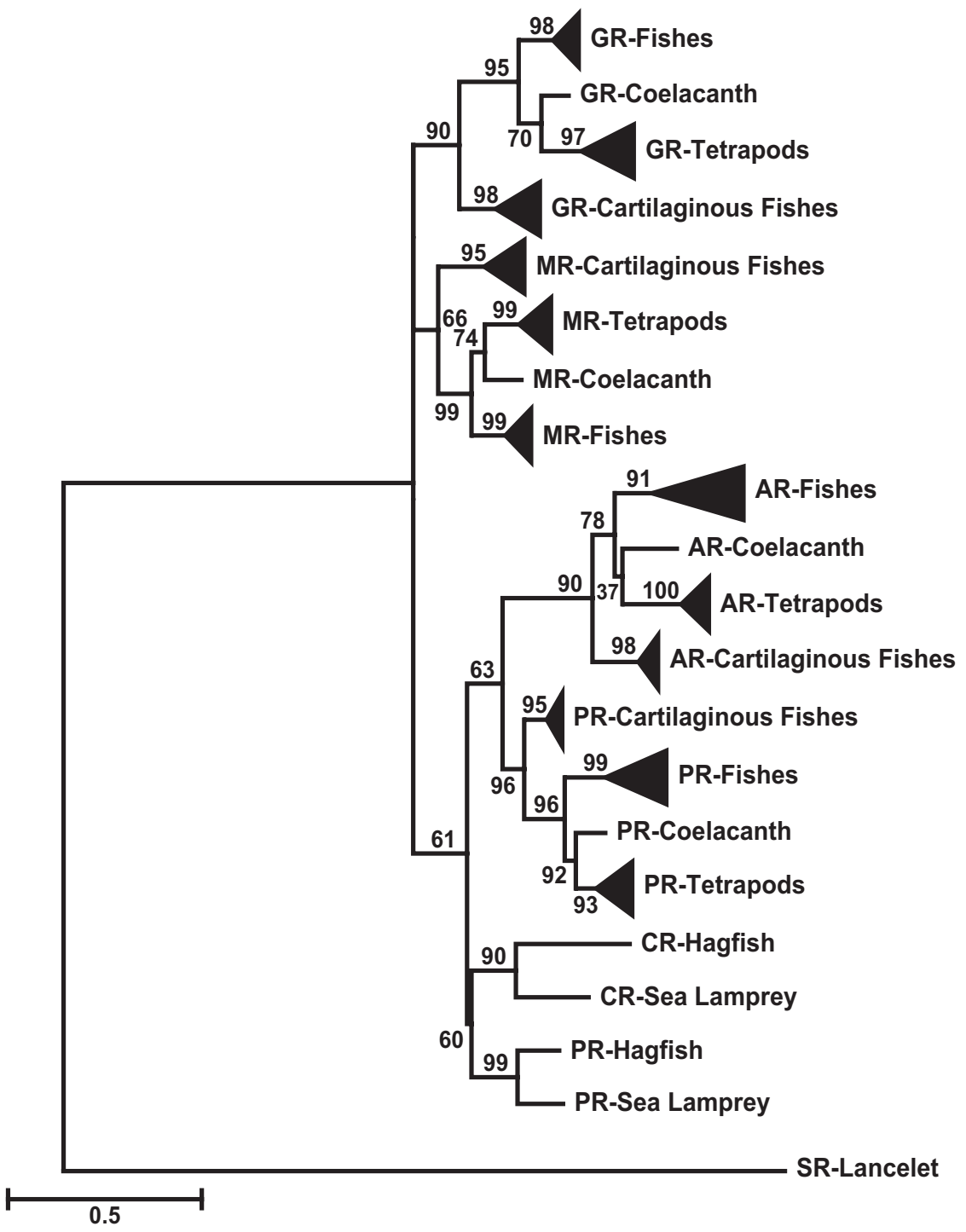

Figure 6

Phylogenetic analysis of vertebrate MRs, GRs, CRs, PRs and ARs. Steroid-binding domains were collected with BLAST searches of GenBank. Then Clustal W2 (Larkin et al. 2007) was used to construct the multiple alignment. The phylogenetic tree was constructed using Maximum Likelihood based on the JTT matrixbased model (Jones et al. 1992). Statistical confidence for each branch in the tree was evaluated with 1,000 bootstrap runs (Tamura et al. 2011). The tree indicates that the $\mathrm{CR} / \mathrm{PR}$ ancestor in an ancestral cyclostome duplicated to form genes that evolved into the CR and PR in modern lampreys and hagfishes. Subsequently, the ancestral CR duplicated, with the surviving $C R$ found in the branch containing descendants in lamprey and hagfish that cluster with lamprey and hagfish PR. The MR and GR are descendants of the other CR that appears to be lost in lamprey and hagfish (Baker et al. 2015, Rossier et al. 2015). In Gnathostomes, a gene duplication produced the AR and PR.
๑) 2017 Society for Endocrinology Printed in Great Britain 
be lost in Pacific and Atlantic lamprey (Baker et al. 2015, Rossier et al. 2015). Also, the presence of the PR in lamprey and hagfish and the absence of an AR in lamprey indicate that the AR evolved from a duplication of an ancestral PR.

\section{Evolution of contacts between the MR and A and $B$ rings on Aldo and other 3-ketosteroids}

Stabilizing interactions between $\alpha$-helix 3 and $\alpha$-helix 5 with each other and with the A and B rings on corticosteroids are important in transcriptional activation of the MR (Geller et al. 2000, Bledsoe et al. 2005, Li et al. 2005, Fuller et al. 2012, Huyet et al. 2012, Baker et al. 2013), as well as other 3-ketosteroid receptors. Consistent with the common ancestry of the MR, GR, $\mathrm{PR}, \mathrm{AR}$ and structural similarities of the $\mathrm{A}$ and $\mathrm{B}$ rings in their canonical ligands, some key amino acids in the $\mathrm{MR}$ are conserved in the GR, PR, AR and CR (Li et al. 2005, Baker et al. 2013, Mani et al. 2016). However, other amino acids are not conserved, providing specificity for mineralocorticoids (Bledsoe et al. 2005, Baker et al. 2007, Huyet et al. 2012, Baker et al. 2013), glucocorticoids (Bledsoe et al. 2002, He et al. 2014), progestins (Williams \& Sigler 1998) and androgens (Sack et al. 2001) in their cognate receptors.

For example, in human MR, Gln-776 (helix 3) and Arg-817 (helix 5) are conserved in corresponding positions in vertebrate MR, GR, PR, AR and CR (Figs 5 and 7) (Baker et al. 2007, 2013). Also conserved in human MR, lamprey CR as well as the GR, PR and AR are contacts between the side chain on Phe-829 (human MR) with the A ring on corticosteroids and between the backbone oxygen on Phe-829 with $\mathrm{N} \varepsilon$ and $\mathrm{N} \eta 2$ on Arg817 (Figs 5 and 7).

\section{Ser-810 (helix 5) in human MR: evolution in the common ancestor of ray-finned and lobe-finned fish}

Ser-810 in human MR also is important in binding of the A ring of steroids. The crystal structure of human MR with Aldo reveals that Ser-810 stabilizes the A ring on Aldo through a hydrogen bond network with two water molecules (Bledsoe et al. 2005). In one hydrogen bond network, a water molecule contacts $\mathrm{O} \gamma$ on Ser-810 and the C3-ketone on Aldo; in another network, a water molecule contacts the backbone oxygen on Ser-810, N 2 on Arg-817 and the C3-ketone on Aldo (Bledsoe et al. 2005) (Fig. 7).
A serine corresponding to Ser-810 in human MR first appears in ray-finned fish and lobe-finned fish (Fig. 5) (Baker et al. 2007, Baker et al. 2011, Baker et al. 2013). In contrast, skate and elephant shark MRs and lamprey and hagfish CRs contain a methionine corresponding to Ser810. Moreover, the GR, PR and AR also have a methionine at this position (Fig. 5) (Baker et al. 2007, 2011, 2013). Thus, this water-mediated hydrogen bond between $\mathrm{O} \gamma$ on Ser-810 and C3-ketone on Aldo, which emerged in the MR in cartilaginous fish (skates and elephant shark), is unique among 3-ketosteroid receptors. The evolution of this serine in the MR affects binding to 3-ketosteroids because, as noted by Bledsoe and coworkers (Bledsoe et al. 2005), methionine at this position cannot participate in a water-mediated hydrogen bond with the C3-ketone on corticosteroids, indicating that there was a change in the mechanism for stabilization of the C3-ketone in the MR in ray-finned fish and tetrapods.

Moreover, as discussed below, it appears that replacement of methionine with serine was important in the loss transcriptional activation of the MR by Prog (Geller et al. 2000) and cortisone (RafestinOblin et al. 2003).

\section{Evolution of the contact between Ser810 (Helix 5) and Ala773 (Helix 3) in human MR: role in the divergence of the MR and GR}

Important evidence for a physiological role of Ser- 810 in human MR comes from a report in 2000 by Geller and coworkers (Geller et al. 2000), who identified a Ser810Leu mutation in the MR, which was activated by Prog (EC50 of $\sim 1 \mathrm{nM}$ ). Prog activation of the MR is unexpected because Prog is an antagonist for wild-type human MR (Kagawa 1958, Wambach \& Higgins 1978, Funder \& Adam 1981, Rupprecht et al. 1993b, Geller et al. 2000, Rafestin-Oblin et al. 2003, Sugimoto et al. 2016). The mineralocorticoid activity of Prog for Leu-810 MR explained high blood pressure in pregnant woman with this mutant MR. In addition, cortisone, which binds poorly to human $\mathrm{MR}$, is an agonist for the Leu-810 MR (Rafestin-Oblin et al. 2003) and could cause hypertension in people with this mutant MR. Moreover, spironolactone, an MR antagonist, activated the Ser810Leu MR in COS-7 cells. Thus, the evolution of an ancestral Ser-810 in the MR in ray-finned fish and tetrapods has an important physiological consequence in preventing activation of the MR by Prog and cortisone. 


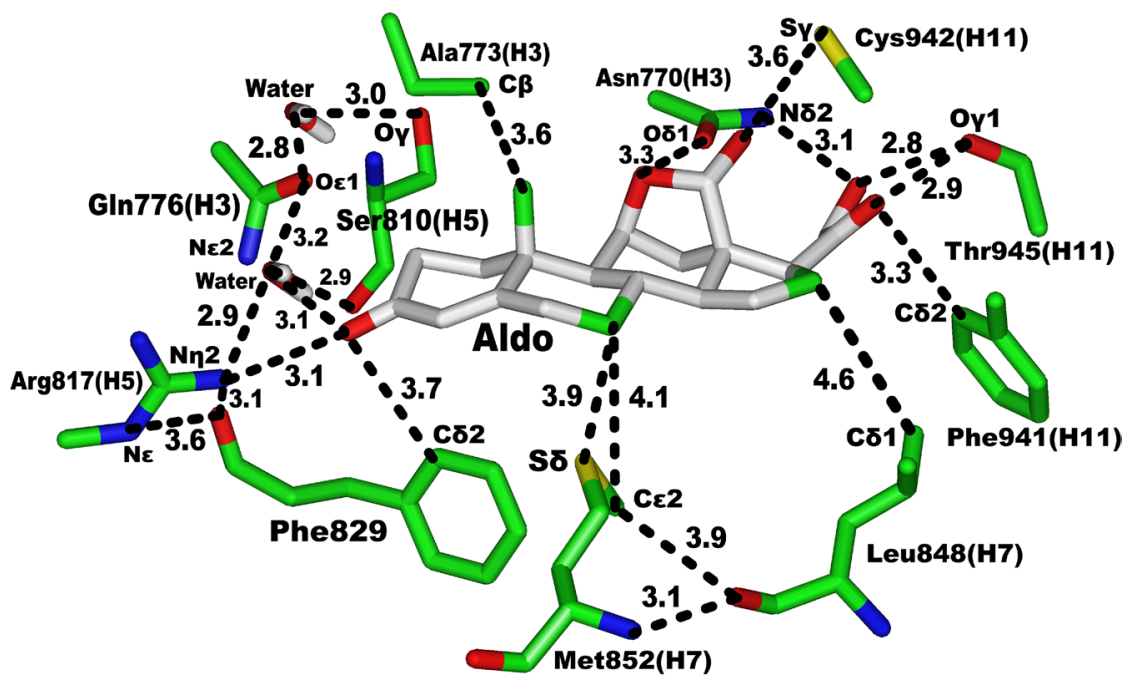

Figure 7

Contacts between the MR and Aldo and two water molecules. Contacts between Aldo with human MR (PDB: 2AA2) (Bledsoe et al. 2005) are shown. Two water molecules mediate contacts between Ser-810 and the A ring of Aldo.
A 3D model of Leu810-MR found a van der Waals contact between Leu-810 and Ala-773 in the mutant MR, which stabilized the contact between helix 3 and helix 5 (Geller et al. 2000). Transcriptional analyses of MRs with mutations at 810 and 773 supported stabilization of the helix 3-helix 5 contact in the agonist activity of Prog. Subsequent crystal structures of Leu810MR found a stabilizing interaction between helix 3 and helix 5 (Bledsoe et al. 2005, Fagart et al. 2005). This contact between Ala-773 and Ser-810 is not found in the crystal structure of wild-type human MR (Bledsoe et al. 2005, Li et al. 2005).

As mentioned previously, Ser-810 evolved in the MR in ray-finned fish and tetrapods. Lamprey and hagfish CR have cysteine (Cys-227) and methionine (Met-264) corresponding to Ala-773 and Ser-810, respectively. A 3D model of lamprey CR found a van der Waals contact between Cys-227 and Met-264 (Baker et al. 2011). In skate and elephant shark MR, this cysteine is replaced with the alanine that is conserved in MR descendants. Based on mutagenesis studies of Geller and coworkers (Geller et al. 2000), we predict that Ala-191 and Met-238 in skate MR and Ala-745 and Met-782 in elephant shark MR (corresponding to human MR Ser-810) will have van der Waals contacts and, thus, Prog will be an agonist for skate and elephant shark MRs.

The evolution of this helix 3-helix 5 contact in the GR affects its response to 3-ketosteroids and the divergence of the GR and MR. Gly-106 in skate GR and Gly-227 in elephant shark GR correspond to Ala-191 in skate MR and Ala-745 in elephant shark MR. The GR in tetrapods and ray-finned fish conserves a corresponding glycine (helix 3) and methionine (helix 5). The human GR crystal structure (Bledsoe et al. 2002, Zhang et al. 2005) reveals, as expected, that Gly-567 (helix 3), which lacks a side chain, does not contact Met-604 (helix 5). Interestingly, replacement of Gly-567 with Ala-567 decreases the response to F, B and DEX by at least 10-fold (Zhang et al. 2005). In skate and elephant shark MR, the corresponding site contains an alanine suggesting that the emergence in cartilaginous fish GRs of a glycine corresponding to Gly-567 in human GR was important in evolution of specificity for glucocorticoids.

\section{Evolution of contacts between the MR and C and $D$ rings on 3-ketosteroids}

Crystal structures of the MR reveal that differences in contacts between the MR and hydroxyl groups on the $\mathrm{C}$ and D rings of 3-ketosteroids (Fig. 2) influence their transcriptional activity for the various MRs, as well as for the GR and other steroid receptors (Bledsoe et al. 2002, Bledsoe et al. 2005, Huang et al. 2010, Huyet et al. 2012).

Vertebrate MRs, CRs and chondrichthyan GR and PR conserve many amino acids in human MR (Fig. 5) that contact the $\mathrm{C}$ and $\mathrm{D}$ rings on Aldo (Fig. 7), DOC and B. These include Asn-770 (helix 3), Met-852 (helix 7), Phe941 (helix 11), Cys-942 (helix 11) and Thr-945 (helix 11) (Fig. 5). Tetrapod and ray-finned fish GRs also conserve amino acids corresponding to Asn-770, Met-852, Cys-942 and Thr-945, but not Phe-941 in human MR. Interestingly, lamprey PR conserves amino acids corresponding to Asn-770, Met-852, Phe-941, Cys-942 and Thr-945 in human MR.
๑) 2017 Society for Endocrinology Printed in Great Britain 


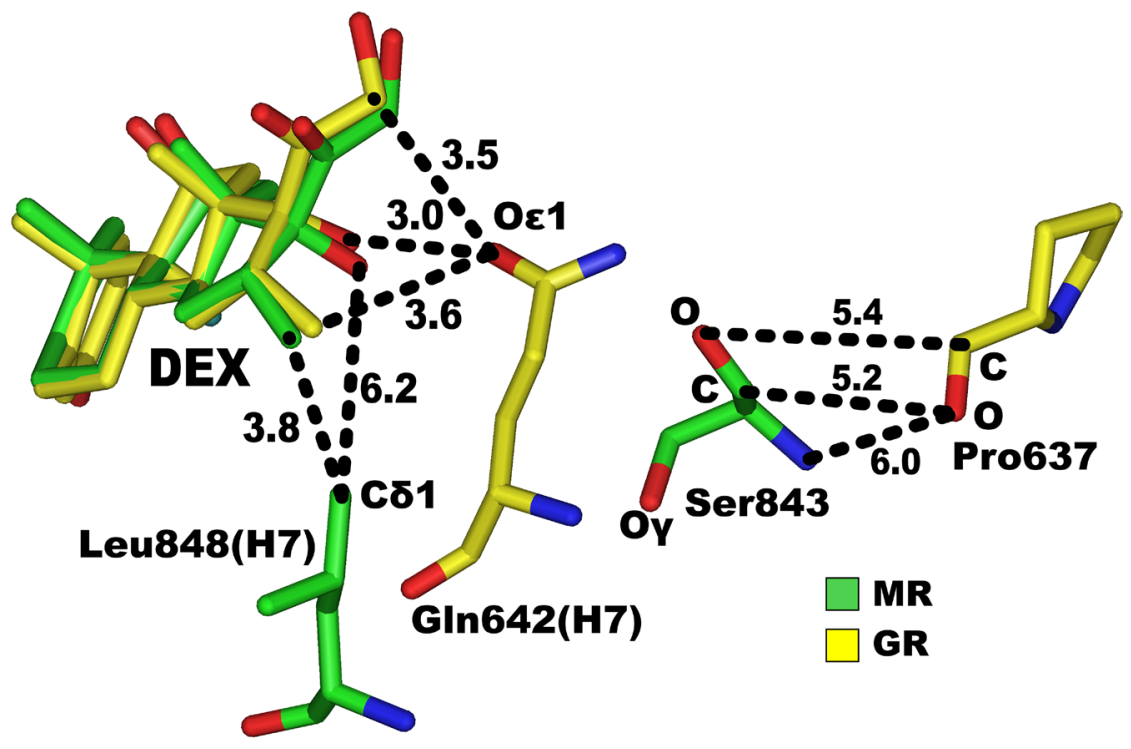

\section{Figure 8}

Comparison of Ser-843/Leu-848 on human MR with Pro-637/GIn-642 on human GR. Human GR complexed with dexamethasone (PDB: 1M2Z) (Bledsoe et al. 2002) and human MR complexed with dexamethasone (PDB: 4UDA) (Edman et al. 2015) were superimposed. In human MR, $C \delta 1$ on Leu- 848 is $6.2 \AA$ and $3.8 \AA$, respectively, from $17 \alpha-\mathrm{OH}$ and $16 \alpha-\mathrm{CH} 3$ on DEX. In human GR, $\mathrm{O} \varepsilon 1$ is $3.0 \AA$ and $3.6 \AA$, respectively, from $17 \alpha-\mathrm{OH}$ and $16 \alpha-\mathrm{CH} 3$ on DEX. Ser-843 and Pro-637 are displaced by over $5 \AA$.

\section{Ser-843 in human MR: Role in divergence from the GR}

Analysis of the crystal structure of the human MR with B (Li et al. 2005) and human GR with DEX (Bledsoe et al. 2002) identified a pocket containing helices 6 and 7 that was present in the GR and not in the MR. This pocket on the GR could accommodate a $17 \alpha$-hydroxyl group on F and DEX and glucocorticoids with other $17 \alpha$ substituents. Two amino acid differences between human MR and GR (Ser-843 and Leu-848 in human MR, Pro-637 and Gln-642 in human GR) (Fig. 5) were identified as important in this conformational change. Indeed, when human GR and MR are superimposed, Ser-843 in the MR is displaced by over $5 \AA$ from Pro-637 in the GR and Leu-848 is $4.5 \AA$ from C16 on B (Baker et al. 2013, Rossier et al. 2015) (Fig. 8), which could be important in different responses between MR and GR to F and DEX (Li et al. 2005). In human GR, Gln-642 has a hydrogen bond with the $17 \alpha$-hydroxyl on DEX (Fig. 8) (Bledsoe et al. 2002, He et al. 2014). In the MR, the hydrophobic side chain on Leu-848 was proposed to clash with the $17 \alpha$-hydroxyl on F and DEX. In contrast, B, Aldo and DOC, which lack a $17 \alpha$-hydroxyl, would not clash with Leu-848, explaining the stronger response of the MR to these steroids. However, a crystal structure of the MR with DEX (Edman et al. 2015) did not find a steric clash between Leu-848 on the MR and the 17 $\alpha$-hydroxyl on DEX due to plasticity in helix6-helix7 in the MR, which allows for an open conformation that can accommodate DEX. A molecular mechanics (Monte Carlo simulations) and crystallographic analysis of the MR, GR, PR, ER and AR revealed that such plasticity is present in MR, GR, PR and ER, but not in the AR. Interestingly, the MR undergoes a larger rearrangement of this region than the GR, which is in a more open configuration (Edman et al. 2015).

Interestingly, $\mathrm{F}$ has low EC50s for fish MRs, which conserve a serine and leucine corresponding to Ser-843 and Leu-848 in human MR. The EC50 of F is $0.02 \mathrm{nM}$ for cichlid (Greenwood et al. 2003, 1).1nM for trout (Sturm et al. 2005, 2).4 nM for carp (Stolte et al. 2008) and $0.22 \mathrm{nM}$ for zebrafish (Pippal et al. 2011).

Nevertheless, the Ser-Pro mutation in the MR likely has some biochemical effect that is important in divergence of the GRs in ray-finned fish and terrestrial vertebrates from the GR and MR in cartilaginous fish. Indeed, mutagenesis of amino acids in an ancestral CR (AncCR) corresponding to Ser-843 and Leu-848 was incorporated into a novel model to investigate the evolution specificity for steroids with $17 \alpha$-hydroxyls such as F for the GR (Bridgham et al. 2006). First, AncCR was transfected into cells and exposed to Aldo or F. The AncCR had a strong response to Aldo and a weak response to F. Then Ser-106 and Leu-111 on AncCR, corresponding to Ser-843 and Leu-848, were mutated to Pro and Gln, as found in ray-finned fish and terrestrial vertebrate GRs. The AncCR-Gln111 mutant had low activity for Aldo, F and DOC, while AncCR-Pro106 was activated by Aldo, DOC and F. The subsequent double AncCR-Pro106/Gln111 mutant had an increased response to $\mathrm{F}$ and low response to Aldo, indicating that the GR evolved from AncCR through a stepwise mutation of Ser-106 to Pro followed by Leu-111 to Gln. However, studies with human MR (Li et al. 2005, Mani et al. 2016) find that Leu843Gln human MR mutant has a favorable response to F, unlike that of the AncCR, leaving unresolved 
the pathway for the formation of Pro and Gln in the GR. Future studies with mutations at the corresponding serine and leucine residues in GRs and MRs in cartilaginous fish should provide more direct data on the pathway for the evolution of specificity for corticosteroids in the GR and MR.

\section{Phosphorylation of Ser-843 inactivates human MR}

An important discovery of another physiological role of Ser-843, also relevant for the Ser to Pro mutation in the GR ancestor of lobe-finned and ray-finned fish, comes from a report by Shibata and coworkers (Shibata et al. 2013) showing that under normal conditions, Ser-843 in human MR is phosphorylated in intercalated cells in the kidney distal tubule and this phosphorylated MR is inactive. De-phosphorylation of Ser- 843 by a phosphatase induced by angiotensin II activates the MR, such that binding of Aldo leads to sodium chloride absorption and potassium secretion. However, because intercalated

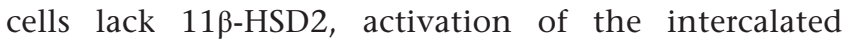
cell MR by de-phosphorylation is followed by $\mathrm{F}$ or B acting as an MR agonist (Funder 2013, Shibata et al. 2013). Interestingly, high potassium levels increase phosphorylation of Ser-843 (Funder 2013, Shibata et al. 2013, Jimenez-Canino et al. 2016). Phosphorylated Ser843 human MR has only been found in intercalated cells in the kidney distal tubule; other tissues such as brain, aorta, heart and colon do not contain phosphorylated Ser-843. Phosphorylation of Ser-843 in the MR in breast and ovary has not been investigated (Funder 2013, Shibata et al. 2013).

A serine corresponding to Ser-843 is found in lamprey and hagfish CR, cartilaginous fish MRs and GRs and lamprey PR. This serine also is conserved in descendant MRs, PRs and ARs. If skate MR Ser-261 and GR Ser-176 and elephant shark MR Ser-815 and GR Ser-297 are phosphorylated in vivo, then the evolution of a corresponding proline in the GR lobe-finned and rayfinned fishes would provide a mechanism for specificity for the regulation of transcriptional activation of the MR through a kinase/phosphatase mechanism that would not affect the GR.

At this time, it is not known if this serine is phosphorylated in lamprey PR or other PRs and ARs, or if phosphorylation alters the response to steroids.

\section{Unanswered questions}

Dobzhansky's aphorism 'Nothing in Biology Makes Sense Except in the Light of Evolution' (Dobzhansky 1973) is our lodestar for investigating the evolution of the MR as well as other steroid receptors and steroidogenic enzymes. In this spirit, we discuss other properties of the MR that merit further investigation to shed light on the evolution of the MR.

\section{Transcriptional activation of fish MR by Prog, a possible mineralocorticoid}

The absence of Aldo in fish has led to speculation that $\mathrm{F}$ and DOC may be a physiological mineralocorticoid for fish (Baker 2003, Sturm et al. 2005, Prunet et al. 2006, Baker et al. 2007, Bury \& Sturm 2007, McCormick et al. 2008, Arterbery et al. 2011, Sakamoto et al. 2011, Takahashi \& Sakamoto 2013, Sakamoto et al. 2016). Interestingly, Prog is a transcriptional activator of ray-finned fish, which also respond to 19-norProg and spironolactone (Sturm et al. 2005, Pippal et al. 2011, Sugimoto et al. 2016). This response is unexpected because Ser-810 in human MR is crucial for the absence of transcriptional activation by Prog, spironolactone and 19-norProg (Geller et al. 2000, Bledsoe et al. 2005, Fagart et al. 2005, Baker et al. 2013), and fish MR contains a serine corresponding to Ser-810 in human MR. The basis for this novel response to Prog, spironolactone and 19-norProg is not known. Nevertheless, Prog may be a physiological mineralocorticoid in fish. Like DOC, Prog lacks an $11 \beta$-hydroxyl and thus is not metabolized by $11 \beta$-HSD2 (Odermatt \& Kratschmar 2012, Chapman et al. 2013). However, serum protein(s) may sequester Prog, reducing its access to fish MRs, as has been found for the effect of corticosteroid binding globulin on access of DOC, B and F to rat MR (Krozowski \& Funder 1983).

\section{Function of Ser-849 in human MR and its deletion in tetrapod and ray-finned fish GRs}

Human MR contains Ser-949 in the loop connecting helix 11 and helix 12. A corresponding serine is found in other MRs, shark GR, the CR, lamprey and human PR and human AR, but not in the GR in tetrapods and ray-finned fish (Fig. 5) (Baker et al. 2007, Baker et al. 2013). The physiological consequences of this serine in human MR
(C) 2017 Society for Endocrinology Printed in Great Britain
Published by Bioscientifica Ltd 


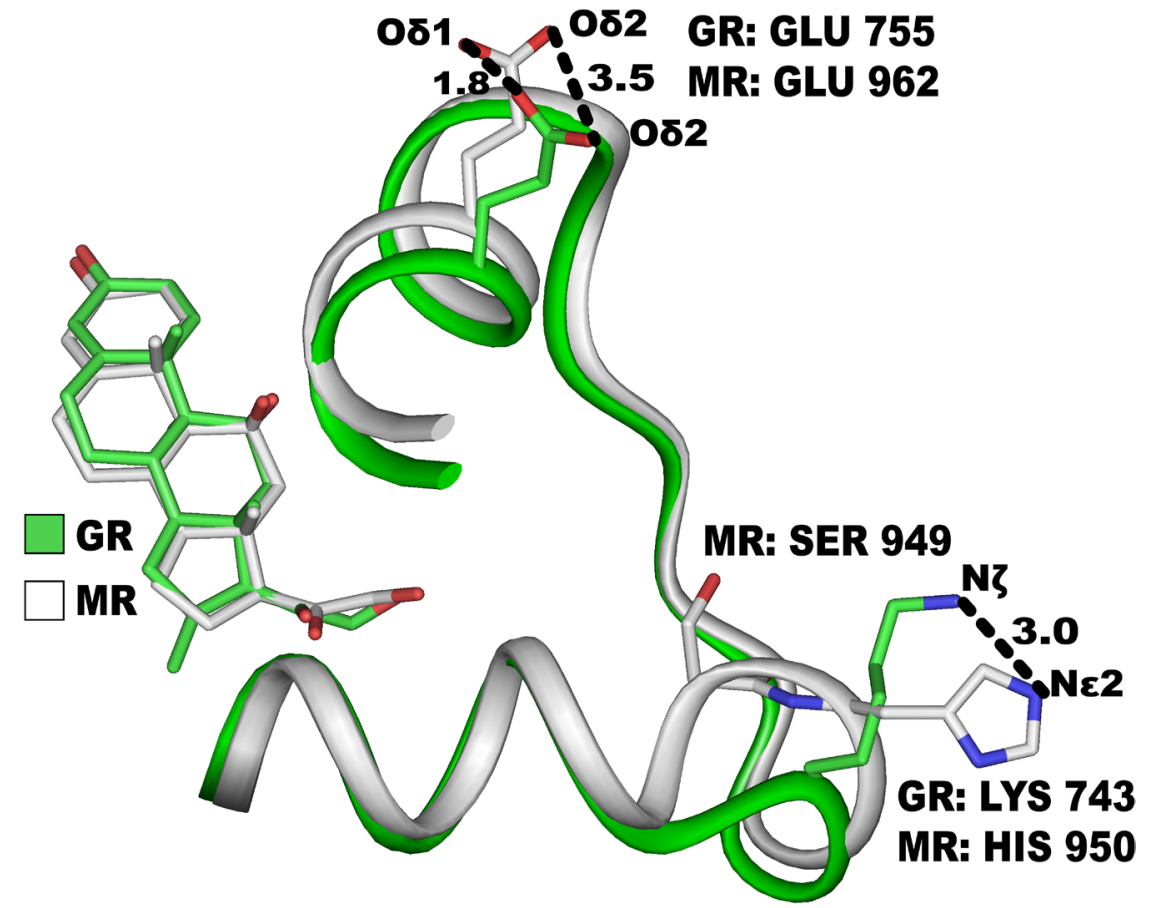

Figure 9

Superposition of helix 12 and the preceding loop in human MR and human GR. Human GR has a deletion corresponding to Ser-949 in human MR, which is in the loop connecting helix 11 and helix 12 in human MR. In human GR, this deletion displaces 082 on Glu-755 in helix 12 on human GR from $0 \delta 2$ on Glu-962 in human MR by $3.5 \AA$. In the loop preceding helix $12, \mathrm{~N} \zeta$ on Lys-743 on human GR is $3 \AA$ from Ne2 on His-950 on human MR. Glu-755 and Glu-962 in the AF2 domain are highly conserved and are part of charge clamp 1 between coactivators and the GR and MR (Li et al. 2005, Kattoula \& Baker 2014). and its deletion in the GR are not known. This difference between the GR and MR appears to alter the conformation of helix 12, which contains AF2, in human GR and MR (Fig. 9). Differences in the conformation of AF2 may be important in selective binding of coactivators to MR and GR (Hultman et al. 2005, Li et al. 2005, Hu \& Funder 2006, Baker et al. 2007, Yang \& Young 2009, Fuller et al. 2012, Baker et al. 2013).

\section{His-950 in human MR: role in the evolution in old world monkeys}

A histidine corresponding to His-950 evolved in the MR in old world monkeys (Baker et al. 2007), which separated from new world monkeys about 40 million years ago. The MR in new world monkeys, other primates, birds, amphibians, coelacanths and ray-finned fish contains glutamine at this position (Fig. 5) (Baker et al. 2013). The functional basis for mutation of a highly conserved glutamine to a histidine, amino acids with different structures, is not known. Nevertheless, the differences between glutamine and histidine suggest that this is not a neutral mutation.

\section{Transcriptional activation by MR-GR heterodimers}

Mammalian MR and GR regulate gene transcription as homodimers (Liu et al. 1995, Mifsud \& Reul 2016).
However, reflecting the kinship of the MR and GR, there is evidence that they form functional heterodimers with different properties from their homodimers (Bradbury et al. 1994, Trapp et al. 1994, Liu et al. 1995, Ou et al. 2001). In human hippocampus, stress increases cortisol to levels that occupy the MR and GR. Cortisol-activated MR-GR heterodimers bind to glucocorticoid response elements, regulating glucocorticoid target genes (Mifsud \& Reul 2016). Recently, heterodimers between trout MR and GR were studied in detail, and the MR in the presence of either cortisol or DOC was found to be a dominant negative repressor of trout GR (Kiilerich et al. 2015). Thus, the actions of the MR and GR in cells that coexpress both receptors are complex and can be influenced by steroids that bind both receptors or are selective for each receptor.

Conservation of functional MR-GR heterodimers over 400 million years suggests that MR-GR heterodimers confer some selective advantage(s) in vertebrates. One possible activity of MR-GR heterodimers in fish comes from cortisol activation of the GR in fish, regulating electrolyte balance (Kumai et al. 2012, Cruz et al. 2013). Mineralocorticoid activity of the GR is surprising and raises the question: what role, if any, does the MR have in osmoregulation in fish? One possibility is that fish MR influences osmoregulation through formation of MR-GR heterodimers. In any event, conservation of heterodimer formation between the MR and its GR kin during the evolution of tetrapods and ray-finned fish and suggests new avenues of research to elucidate

Published by Bioscientifica Ltd. 
physiological responses to corticosteroids by the MR and GR.

\section{Conclusion}

The cloning of the MR (Arriza et al. 1987) coincides with the beginning of a renaissance in evolutionary biology due to the explosive increase in the number sequences of receptors, transcription factors and enzymes deposited in GenBank. This cornucopia of sequences required new software to extract and manage the information in the sequences for application to control diseases, which facilitated analyses that provided insights into the evolution of steroid receptors and other nuclear receptors (Evans 1988, Laudet et al. 1992, Baker 1997). The insight that the MR and GR were kin has been important for applying information about each receptor to understanding mineralocorticoid and glucocorticoid responses in normal physiology and in treatment of endocrine-dependent diseases. With the current explosive increase in genomic sequences, in which thousands of human genomes can be studied for mutations, we can expect new insights into the molecular basis for diseases dependent on the MR, GR and their ligands (Markov et al. 2009, Hawkins et al. 2012, Nelson et al. 2013, de Kloet 2014, Gomez-Sanchez \& Gomez-Sanchez 2014, Baker et al. 2015, Fuller 2015, Rossier et al. 2015, de Kloet et al. 2016, Jaisser \& Farman 2016).

\section{Supplementary data}

This is linked to the online version of the paper at http://dx.doi.org/10.1530/ JOE-16-0661.

\section{Declaration of interest}

$M E B$ and $Y K$ have no conflict of interest.

\section{Funding}

Y $\mathrm{K}$ was supported in part by Grants-in-Aid for Scientific Research [26440159] from the Ministry of Education, Culture, Sports, Science and Technology of Japan. M E B was supported by Research fund \#3096.

Author contribution statement

$\mathrm{M} \mathrm{E} \mathrm{B}$ and $\mathrm{Y} \mathrm{K}$ conceived of and wrote the paper.

\section{Acknowledgement}

We gratefully acknowledge valuable discussions with Dr Romain Studer regarding the phylogenetic analysis of the MR and other steroid receptors. We thank Drs Karl Edman and Victor Guallar for informative discussion on Monte Carlo simulations of the MR and other steroid receptors.

\section{References}

Arriza JL, Simerly RB, Swanson LW \& Evans RM 1988 The neuronal mineralocorticoid receptor as a mediator of glucocorticoid response. Neuron 1 887-900. (doi:10.1016/0896-6273(88)90136-5)

Arriza JL, Weinberger C, Cerelli G, Glaser TM, Handelin BL, Housman DE \& Evans RM 1987 Cloning of human mineralocorticoid receptor complementary DNA: structural and functional kinship with the glucocorticoid receptor. Science 237 268-275. (doi:10.1126/ science.3037703)

Arterbery AS, Fergus DJ, Fogarty EA, Mayberry J, Deitcher DL, Lee Kraus W \& Bass AH 2011 Evolution of ligand specificity in vertebrate corticosteroid receptors. BMC Evolutionary Biology 1114. (doi:10.1186/1471-2148-11-14)

Baker ME 1997 Steroid receptor phylogeny and vertebrate origins. Molecular and Cellular Endocrinology 135 101-107. (doi:10.1016/S03037207(97)00207-4)

Baker ME 2003 Evolution of glucocorticoid and mineralocorticoid responses: go fish. Endocrinology 144 4223-4225. (doi:10.1210/ en.2003-0843)

Baker ME 2010 11Beta-hydroxysteroid dehydrogenase-type 2 evolved from an ancestral 17beta-hydroxysteroid dehydrogenase-type 2 . Biochemical and Biophysical Research Communications 399 215-220. (doi:10.1016/j.bbrc.2010.07.057)

Baker ME 2011 Origin and diversification of steroids: co-evolution of enzymes and nuclear receptors. Molecular and Cellular Endocrinology 334 14-20. (doi:10.1016/j.mce.2010.07.013)

Baker ME, Chandsawangbhuwana C \& Ollikainen N 2007 Structural analysis of the evolution of steroid specificity in the mineralocorticoid and glucocorticoid receptors. BMC Evolutionary Biology 7 24. (doi:10.1186/1471-2148-7-24)

Baker ME, Funder JW \& Kattoula SR 2013 Evolution of hormone selectivity in glucocorticoid and mineralocorticoid receptors. Journal of Steroid Biochemistry and Molecular Biology 137 57-70. (doi:10.1016/j. jsbmb.2013.07.009)

Baker ME, Nelson DR \& Studer RA 2015 Origin of the response to adrenal and sex steroids: Roles of promiscuity and co-evolution of enzymes and steroid receptors. Journal of Steroid Biochemistry and Molecular Biology 151 12-24. (doi:10.1016/j.jsbmb.2014.10.020)

Baker ME, Uh KY \& Asnaashari P 2011 3D models of lamprey corticoid receptor complexed with 11-deoxycortisol and deoxycorticosterone. Steroids 76 1451-1457. (doi:10.1016/j.steroids.2011.07.015)

Bledsoe RK, Madauss KP, Holt JA, Apolito CJ, Lambert MH, Pearce KH, Stanley TB, Stewart EL, Trump RP, Willson TM, et al. 2005 A ligandmediated hydrogen bond network required for the activation of the mineralocorticoid receptor. Journal of Biological Chemistry $\mathbf{2 8 0}$ 31283-31293. (doi:10.1074/jbc.M504098200)

Bledsoe RK, Montana VG, Stanley TB, Delves CJ, Apolito CJ, McKee DD, Consler TG, Parks DJ, Stewart EL, Willson TM, et al. 2002 Crystal structure of the glucocorticoid receptor ligand binding domain reveals a novel mode of receptor dimerization and coactivator recognition. Cell 110 93-105. (doi:10.1016/S0092-8674(02)00817-6)

Bradbury MJ, Akana SF \& Dallman MF 1994 Roles of type I and II corticosteroid receptors in regulation of basal activity in the hypothalamo-pituitary-adrenal axis during the diurnal trough and the peak: evidence for a nonadditive effect of combined

http://joe.endocrinology-journals.org
$\begin{aligned} & \text { DOI: } 10.1530 / \text { JOE-16-0661 } 2017 \text { Society for Endocrinology } \\ & \text { Printed in Great Britain }\end{aligned}$


receptor occupation. Endocrinology 134 1286-1296. (doi:10.1210/ endo.134.3.8119168)

Bridgham JT, Brown JE, Rodriguez-Mari A, Catchen JM \& Thornton JW 2008 Evolution of a new function by degenerative mutation in cephalochordate steroid receptors. PLoS Genetics 4 e1000191. (doi:10.1371/journal.pgen.1000191)

Bridgham JT, Carroll SM \& Thornton JW 2006 Evolution of hormonereceptor complexity by molecular exploitation. Science 312 97-101. (doi:10.1126/science.1123348)

Bridgham JT, Eick GN, Larroux C, Deshpande K, Harms MJ, Gauthier ME, Ortlund EA, Degnan BM \& Thornton JW 2010 Protein evolution by molecular tinkering: diversification of the nuclear receptor superfamily from a ligand-dependent ancestor. PLoS Biology $\mathbf{8}$ e1000497. (doi:10.1371/journal.pbio.1000497)

Bury NR \& Sturm A 2007 Evolution of the corticosteroid receptor signalling pathway in fish. General and Comparative Endocrinology 153 47-56. (doi:10.1016/j.ygcen.2007.03.009)

Carroll SM, Bridgham JT \& Thornton JW 2008 Evolution of hormone signaling in elasmobranchs by exploitation of promiscuous receptors. Molecular Biology and Evolution 25 2643-2652. (doi:10.1093/molbev/ msn204)

Chapman K, Holmes M \& Seckl J 2013 11beta-hydroxysteroid dehydrogenases: intracellular gate-keepers of tissue glucocorticoid action. Physiological Reviews 93 1139-1206. (doi:10.1152/ physrev.00020.2012)

Close DA, Yun SS, McCormick SD, Wildbill AJ \& Li W 2010 11-deoxycortisol is a corticosteroid hormone in the lamprey. PNAS 107 13942-13947. (doi:10.1073/pnas.0914026107)

Cruz SA, Lin CH, Chao PL \& Hwang PP 2013 Glucocorticoid receptor, but not mineralocorticoid receptor, mediates cortisol regulation of epidermal ionocyte development and ion transport in zebrafish (danio rerio). PLoS One 8 e77997. (doi:10.1371/journal.pone.0077997)

de Kloet ER 2014 From receptor balance to rational glucocorticoid therapy. Endocrinology 155 2754-2769. (doi:10.1210/en.2014-1048)

de Kloet ER, Otte C, Kumsta R, Kok L, Hillegers MH, Hasselmann H, Kliegel D \& Joels M 2016 Stress and depression: a crucial role of the mineralocorticoid receptor. Journal of Neuroendocrinology $\mathbf{2 8}$ article 12379. (doi:10.1111/jne.12379)

Dobzhansky T 1973 Nothing in Biology Makes Sense except in the Light of Evolution. American Biology Teacher 35 125-129. (doi:10.2307/4444260)

Draper N \& Stewart PM 2005 11beta-hydroxysteroid dehydrogenase and the pre-receptor regulation of corticosteroid hormone action. Journal of Endocrinology 186 251-271. (doi:10.1677/joe.1.06019)

Edman K, Hosseini A, Bjursell MK, Aagaard A, Wissler L, Gunnarsson A, Kaminski T, Kohler C, Backstrom S, Jensen TJ, et al. 2015 Ligand binding mechanism in steroid receptors: from conserved plasticity to differential evolutionary constraints. Structure 23 2280-2290. (doi:10.1016/j.str.2015.09.012)

Edwards CR, Stewart PM, Burt D, Brett L, McIntyre MA, Sutanto WS, de Kloet ER \& Monder C 1988 Localisation of 11 beta-hydroxysteroid dehydrogenase--tissue specific protector of the mineralocorticoid receptor. Lancet 2 986-989. (doi:10.1016/S0140-6736(88)90742-8)

Evans RM 1988 The steroid and thyroid hormone receptor superfamily. Science 240 889-895. (doi:10.1126/science.3283939)

Fagart J, Huyet J, Pinon GM, Rochel M, Mayer C \& Rafestin-Oblin ME 2005 Crystal structure of a mutant mineralocorticoid receptor responsible for hypertension. Nature Structural \& Molecular Biology 12 554-555. (doi:10.1038/nsmb93)

Fagart J, Wurtz JM, Souque A, Hellal-Levy C, Moras D \& Rafestin-Oblin ME 1998 Antagonism in the human mineralocorticoid receptor. EMBO Journal 17 3317-3325. (doi:10.1093/emboj/17.12.3317)

Faresse N 2014 Post-translational modifications of the mineralocorticoid receptor: How to dress the receptor according to the circumstances? Journal of Steroid Biochemistry and Molecular Biology 143 334-342. (doi:10.1016/j.jsbmb.2014.04.015)
Fuller PJ 2015 Novel interactions of the mineralocorticoid receptor Molecular and Cellular Endocrinology 408 33-37. (doi:10.1016/j. mce.2015.01.027)

Fuller PJ, Yao Y, Yang J \& Young MJ 2012 Mechanisms of ligand specificity of the mineralocorticoid receptor. Journal of Endocrinology 213 15-24. (doi:10.1530/JOE-11-0372)

Funder JW 2013 Angiotensin retains sodium by dephosphorylating mineralocorticoid receptors in renal intercalated cells. Cell Metabolism 18 609-610. (doi:10.1016/j.cmet.2013.10.010)

Funder JW \& Adam WR 1981 19-Nor progesterone is a mineralocorticoid agonist. Endocrinology 109 313-315. (doi:10.1210/endo-109-1-313)

Funder JW, Pearce PT, Smith R \& Smith AI 1988 Mineralocorticoid action: target tissue specificity is enzyme, not receptor, mediated. Science $\mathbf{2 4 2}$ 583-585. (doi:10.1126/science.2845584)

Geller DS, Farhi A, Pinkerton N, Fradley M, Moritz M, Spitzer A, Meinke G, Tsai FT, Sigler PB \& Lifton RP 2000 Activating mineralocorticoid receptor mutation in hypertension exacerbated by pregnancy. Science 289 119-123. (doi:10.1126/science.289.5476.119)

Gomez-Sanchez E \& Gomez-Sanchez CE 2014 The multifaceted mineralocorticoid receptor. Comprehensive Physiology 4 965-994. (doi:10.1002/cphy.c130044)

Greenwood AK, Butler PC, White RB, DeMarco U, Pearce D \& Fernald RD 2003 Multiple corticosteroid receptors in a teleost fish: distinct sequences, expression patterns, and transcriptional activities. Endocrinology 144 4226-4236. (doi:10.1210/en.2003-0566)

Hawkins UA, Gomez-Sanchez EP, Gomez-Sanchez CM \& GomezSanchez CE 2012 The ubiquitous mineralocorticoid receptor: clinical implications. Current Hypertension Reports 14 573-580. (doi:10.1007/ s11906-012-0297-0)

He Y, Yi W, Suino-Powell K, Zhou XE, Tolbert WD, Tang X, Yang J, Yang H, Shi J, Hou L, et al. 2014 Structures and mechanism for the design of highly potent glucocorticoids. Cell Research 24 713-726. (doi:10.1038/cr.2014.52)

Hellal-Levy C, Couette B, Fagart J, Souque A, Gomez-Sanchez C \& Rafestin-Oblin M 1999 Specific hydroxylations determine selective corticosteroid recognition by human glucocorticoid and mineralocorticoid receptors. FEBS Letters 464 9-13. (doi:10.1016/ S0014-5793(99)01667-1)

Hu X \& Funder JW 2006 The evolution of mineralocorticoid receptors. Molecular Endocrinology 20 1471-1478. (doi:10.1210/me.2005-0247)

Huang P, Chandra V \& Rastinejad F 2010 Structural overview of the nuclear receptor superfamily: insights into physiology and therapeutics. Annual Review of Physiology 72 247-272. (doi:10.1146/ annurev-physiol-021909-135917)

Hultman ML, Krasnoperova NV, Li S, Du S, Xia C, Dietz JD, Lala DS, Welsch DJ \& Hu X 2005 The ligand-dependent interaction of mineralocorticoid receptor with coactivator and corepressor peptides suggests multiple activation mechanisms. Molecular Endocrinology 19 1460-1473. (doi:10.1210/me.2004-0537)

Huyet J, Pinon GM, Fay MR, Rafestin-Oblin ME \& Fagart J 2012 Structural determinants of ligand binding to the mineralocorticoid receptor. Molecular and Cellular Endocrinology 350 187-195. (doi:10.1016/j. mce.2011.07.035)

Jaisser F \& Farman N 2016 Emerging roles of the mineralocorticoid receptor in pathology: toward new paradigms in clinical pharmacology. Pharmacological Reviews 68 49-75. (doi:10.1124/pr.115.011106)

Jiang JQ, Young G, Kobayashi T \& Nagahama Y 1998 Eel (Anguilla japonica) testis 11beta-hydroxylase gene is expressed in interrenal tissue and its product lacks aldosterone synthesizing activity. Molecular and Cellular Endocrinology 146 207-211. (doi:10.1016/S03037207(98)00147-6)

Jimenez-Canino R, Fernandes MX \& Alvarez de la Rosa D 2016 Phosphorylation of mineralocorticoid receptor ligand binding domain impairs receptor activation and has a dominant negative effect over non-phosphorylated receptors. Journal of Biological Chemistry 291 19068-19078. (doi:10.1074/jbc.M116.718395) 
Jones DT, Taylor WR \& Thornton JM 1992 The rapid generation of mutation data matrices from protein sequences. Computer Applications in the Biosciences 8 275-282. (doi:10.1093/bioinformatics/8.3.275)

Joss JMP, Arnoldreed DE \& Balment RJ 1994 The Steroidogenic Response to Angiotensin-Ii in the Australian Lungfish, Neoceratodus-Forsteri. Journal of Comparative Physiology B: Biochemical Systemic and Environmental Physiology 164 378-382. (doi:10.1007/BF00302553)

Kagawa CM 1958 Blocking urinary electrolyte effects of desoxycorticosterone with progesterone in rats. Proceedings of the Society for Experimental Biology and Medicine 99 705-707. (doi:10.3181/00379727-99-24471)

Kassahn KS, Ragan MA \& Funder JW 2011 Mineralocorticoid receptors: evolutionary and pathophysiological considerations. Endocrinology 152 1883-1890. (doi:10.1210/en.2010-1444)

Katsu Y, Kohno S, Oka K \& Baker ME 2016 Evolution of corticosteroid specificity for human, chicken, alligator and frog glucocorticoid receptors. Steroids 113 38-45. (doi:10.1016/j.steroids.2016.06.005)

Katsu Y, Kubokawa K, Urushitani H \& Iguchi T 2010 Estrogen-dependent transactivation of amphioxus steroid hormone receptor via both estrogen and androgen response elements. Endocrinology 151 639-648. (doi:10.1210/en.2009-0766)

Kattoula SR \& Baker ME 2014 Structural and evolutionary analysis of the co-activator binding domain in vertebrate progesterone receptors. Journal of Steroid Biochemistry and Molecular Biology 141 7-15. (doi:10.1016/j.jsbmb.2013.12.018)

Kiilerich P, Triqueneaux G, Christensen NM, Trayer V, Terrien X, Lombes M \& Prunet P 2015 Interaction between the trout mineralocorticoid and glucocorticoid receptors in vitro. Journal of Molecular Endocrinology 55 55-68. (doi:10.1530/JME-15-0002)

Krozowski ZS \& Funder JW 1983 Renal mineralocorticoid receptors and hippocampal corticosterone-binding species have identical intrinsic steroid specificity. PNAS 80 6056-6060. (doi:10.1073/ pnas.80.19.6056)

Kumai Y, Nesan D, Vijayan MM \& Perry SF 2012 Cortisol regulates $\mathrm{Na}+$ uptake in zebrafish, Danio rerio, larvae via the glucocorticoid receptor. Molecular and Cellular Endocrinology 364 113-125. (doi:10.1016/j.mce.2012.08.017)

Lam EY, Funder JW, Nikolic-Paterson DJ, Fuller PJ \& Young MJ 2006 Mineralocorticoid receptor blockade but not steroid withdrawal reverses renal fibrosis in deoxycorticosterone/salt rats. Endocrinology 147 3623-3629. (doi:10.1210/en.2005-1527)

Larkin MA, Blackshields G, Brown NP, Chenna R, McGettigan PA, McWilliam H, Valentin F, Wallace IM, Wilm A, Lopez R, et al. 2007 Clustal W and Clustal X version 2.0. Bioinformatics 23 2947-2948. (doi:10.1093/bioinformatics/btm404)

Laudet V, Hanni C, Coll J, Catzeflis F \& Stehelin D 1992 Evolution of the nuclear receptor gene superfamily. EMBO Journal 11 1003-1013.

Li Y, Suino K, Daugherty J \& Xu HE 2005 Structural and biochemical mechanisms for the specificity of hormone binding and coactivator assembly by mineralocorticoid receptor. Molecular Cell 19 367-380. (doi:10.1016/j.molcel.2005.06.026)

Lim-Tio SS, Keightley MC \& Fuller PJ 1997 Determinants of specificity of transactivation by the mineralocorticoid or glucocorticoid receptor. Endocrinology 138 2537-2543. (doi:10.1210/ endo.138.6.5214)

Liu W, Wang J, Sauter NK \& Pearce D 1995 Steroid receptor heterodimerization demonstrated in vitro and in vivo. PNAS 92 12480-12484. (doi:10.1073/pnas.92.26.12480)

Lombes M, Kenouch S, Souque A, Farman N \& Rafestin-Oblin ME 1994 The mineralocorticoid receptor discriminates aldosterone from glucocorticoids independently of the 11 beta-hydroxysteroid dehydrogenase. Endocrinology 135 834-840. (doi:10.1210/ endo.135.3.8070376)

Mani O, Nashev LG, Livelo C, Baker ME \& Odermatt A 2016 Role of Pro-637 and Gln-642 in human glucocorticoid receptors and Ser-843 and Leu-848 in mineralocorticoid receptors in their differential

http://joe.endocrinology-journals.org

DOI: 10.1530/JOE-16-0661
(C) 2017 Society for Endocrinology Printed in Great Britain responses to cortisol and aldosterone. Journal of Steroid Biochemistry and Molecular Biology 159 31-40. (doi:10.1016/j.jsbmb.2016.02.017)

Markov GV, Tavares R, Dauphin-Villemant C, Demeneix BA, Baker ME \& Laudet V 2009 Independent elaboration of steroid hormone signaling pathways in metazoans. PNAS 106 11913-11918. (doi:10.1073/ pnas.0812138106)

Martinerie L, Munier M, Le Menuet D, Meduri G, Viengchareun S \& Lombes M 2013 The mineralocorticoid signaling pathway throughout development: expression, regulation and pathophysiological implications. Biochimie 95 148-157. (doi:10.1016/j.biochi.2012.09.030)

McCormick SD, Regish A, O'Dea MF \& Shrimpton JM 2008 Are we missing a mineralocorticoid in teleost fish? Effects of cortisol, deoxycorticosterone and aldosterone on osmoregulation, gill $\mathrm{Na}+, \mathrm{K}+-\mathrm{ATPase}$ activity and isoform mRNA levels in Atlantic salmon. General and Comparative Endocrinology 157 35-40. (doi:10.1016/j.ygcen.2008.03.024)

Mifsud KR \& Reul JM 2016 Acute stress enhances heterodimerization and binding of corticosteroid receptors at glucocorticoid target genes in the hippocampus. PNAS 113 11336-11341. (doi:10.1073/ pnas.1605246113)

Myles K \& Funder JW 1994 Type I (mineralocorticoid) receptors in the guinea pig. American Journal of Physiology 267 E268-E272.

Myles K \& Funder JW 1996 Progesterone binding to mineralocorticoid receptors: in vitro and in vivo studies. American Journal of Physiology 270 E601-E607.

Nelson DR, Goldstone JV \& Stegeman JJ 2013 The cytochrome P450 genesis locus: the origin and evolution of animal cytochrome P450s. Philosophical Transactions of the Royal Society B: Biological Sciences 368 20120474. (doi:10.1098/rstb.2012.0474)

Odermatt A \& Kratschmar DV 2012 Tissue-specific modulation of mineralocorticoid receptor function by 11beta-hydroxysteroid dehydrogenases: an overview. Molecular and Cellular Endocrinology 350 168-186. (doi:10.1016/j.mce.2011.07.020)

Oka K, Hoang A, Okada D, Iguchi T, Baker ME \& Katsu Y 2015 Allosteric role of the amino-terminal A/B domain on corticosteroid transactivation of gar and human glucocorticoid receptors. Journal of Steroid Biochemistry and Molecular Biology 154 112-119. (doi:10.1016/j. jsbmb.2015.07.025)

Osorio J \& Retaux S 2008 The lamprey in evolutionary studies. Development Genes and Evolution 218 221-235. (doi:10.1007/s00427008-0208-1)

Ou XM, Storring JM, Kushwaha N \& Albert PR 2001 Heterodimerization of mineralocorticoid and glucocorticoid receptors at a novel negative response element of the 5-HT1A receptor gene. Journal of Biological Chemistry 276 14299-14307. (doi:10.1074/jbc.M005363200)

Paris M, Pettersson K, Schubert M, Bertrand S, Pongratz I, Escriva H \& Laudet V 2008 An amphioxus orthologue of the estrogen receptor that does not bind estradiol: insights into estrogen receptor evolution. BMC Evolutionary Biology 8 219. (doi:10.1186/1471-2148-8-219)

Pascual-Le Tallec L \& Lombes M 2005 The mineralocorticoid receptor: a journey exploring its diversity and specificity of action. Molecular Endocrinology 19 2211-2221. (doi:10.1210/me.2005-0089)

Pearce D \& Yamamoto KR 1993 Mineralocorticoid and glucocorticoid receptor activities distinguished by nonreceptor factors at a composite response element. Science 259 1161-1165. (doi:10.1126/ science.8382376)

Pippal JB, Cheung CM, Yao YZ, Brennan FE \& Fuller PJ 2011 Characterization of the zebrafish (Danio rerio) mineralocorticoid receptor. Molecular and Cellular Endocrinology 332 58-66. (doi:10.1016/j.mce.2010.09.014)

Pippal JB, Yao Y, Rogerson FM \& Fuller PJ 2009 Structural and functional characterization of the interdomain interaction in the mineralocorticoid receptor. Molecular Endocrinology 23 1360-1370. (doi:10.1210/me.2009-0032)

Prunet P, Sturm A \& Milla S 2006 Multiple corticosteroid receptors in fish: from old ideas to new concepts. General and Comparative Endocrinology 147 17-23. (doi:10.1016/j.ygcen.2006.01.015) 
Rafestin-Oblin ME, Souque A, Bocchi B, Pinon G, Fagart J \& Vandewalle A 2003 The severe form of hypertension caused by the activating S810L mutation in the mineralocorticoid receptor is cortisone related. Endocrinology 144 528-533. (doi:10.1210/en.2002-220708)

Roberts BW, Didier W, Rai S, Johnson NS, Libants S, Yun SS \& Close DA 2014 Regulation of a putative corticosteroid, 17,21-dihydroxypregn4-ene,3,20-one, in sea lamprey, Petromyzon marinus. General and Comparative Endocrinology 196 17-25. (doi:10.1016/j.ygcen.2013.11.008)

Rogerson FM \& Fuller PJ 2003 Interdomain interactions in the mineralocorticoid receptor. Molecular and Cellular Endocrinology 200 45-55. (doi:10.1016/S0303-7207(02)00413-6)

Rossier BC, Baker ME \& Studer RA 2015 Epithelial sodium transport and its control by aldosterone: the story of our internal environment revisited. Physiological Reviews 95 297-340. (doi:10.1152/physrev.00011.2014)

Rupprecht R, Arriza JL, Spengler D, Reul JM, Evans RM, Holsboer F \& Damm K 1993a Transactivation and synergistic properties of the mineralocorticoid receptor: relationship to the glucocorticoid receptor. Molecular Endocrinology 7 597-603. (doi:10.1210/me.7.4.597)

Rupprecht R, Reul JM, van Steensel B, Spengler D, Soder M, Berning B, Holsboer F \& Damm K 1993b Pharmacological and functional characterization of human mineralocorticoid and glucocorticoid receptor ligands. European Journal of Pharmacology 247 145-154. (doi:10.1016/0922-4106(93)90072-H)

Sack JS, Kish KF, Wang C, Attar RM, Kiefer SE, An Y, Wu GY, Scheffler JE, Salvati ME, Krystek SR, Jr, et al. 2001 Crystallographic structures of the ligand-binding domains of the androgen receptor and its T877A mutant complexed with the natural agonist dihydrotestosterone. PNAS 98 4904-4909. (doi:10.1073/pnas.081565498)

Sakamoto T, Mori C, Minami S, Takahashi H, Abe T, Ojima D, Ogoshi M \& Sakamoto H 2011 Corticosteroids stimulate the amphibious behavior in mudskipper: potential role of mineralocorticoid receptors in teleost fish. Physiology \& Behavior 104 923-928. (doi:10.1016/j. physbeh.2011.06.002)

Sakamoto T, Yoshiki M, Takahashi H, Yoshida M, Ogino Y, Ikeuchi T, Nakamachi T, Konno N, Matsuda K \& Sakamoto H 2016 Principal function of mineralocorticoid signaling suggested by constitutive knockout of the mineralocorticoid receptor in medaka fish. Scientific Reports 6 37991. (doi:10.1038/srep37991)

Sauka-Spengler T \& Bronner-Fraser M 2008 Insights from a sea lamprey into the evolution of neural crest gene regulatory network. Biological Bulletin 214 303-314. (doi:10.2307/25470671)

Shibata S, Rinehart J, Zhang J, Moeckel G, Castaneda-Bueno M, Stiegler AL, Boggon TJ, Gamba G \& Lifton RP 2013 Mineralocorticoid receptor phosphorylation regulates ligand binding and renal response to volume depletion and hyperkalemia. Cell Metabolism 18 660-671. (doi:10.1016/j.cmet.2013.10.005)

Stolte EH, de Mazon AF, Leon-Koosterziel KM, Jesiak M, Bury NR, Sturm A, Savelkoul HF, van Kemenade BM \& Flik G 2008 Corticosteroid receptors involved in stress regulation in common carp, Cyprinus carpio. Journal of Endocrinology 198 403-417. (doi:10.1677/JOE-08-0100)
Sturm A, Bury N, Dengreville L, Fagart J, Flouriot G, Rafestin-Oblin ME \& Prunet P 2005 11-deoxycorticosterone is a potent agonist of the rainbow trout (Oncorhynchus mykiss) mineralocorticoid receptor. Endocrinology 146 47-55. (doi:10.1210/en.2004-0128)

Sugimoto A, Oka K, Sato R, Adachi S, Baker ME \& Katsu Y 2016 Corticosteroid and progesterone transactivation of mineralocorticoid receptors from Amur sturgeon and tropical gar. Biochemical Journal 473 3655-3665. (doi:10.1042/BCJ20160579)

Takahashi H \& Sakamoto T 2013 The role of 'mineralocorticoids' in teleost fish: relative importance of glucocorticoid signaling in the osmoregulation and 'central' actions of mineralocorticoid receptor. General and Comparative Endocrinology 181 223-228. (doi:10.1016/j. ygcen.2012.11.016)

Tamura K, Peterson D, Peterson N, Stecher G, Nei M \& Kumar S 2011 MEGA5: molecular evolutionary genetics analysis using maximum likelihood, evolutionary distance, and maximum parsimony methods. Molecular Biology and Evolution 28 2731-2739. (doi:10.1093/ molbev/msr121)

Thornton JW 2001 Evolution of vertebrate steroid receptors from an ancestral estrogen receptor by ligand exploitation and serial genome expansions. PNAS 98 5671-5676. (doi:10.1073/pnas.091553298)

Trapp T, Rupprecht R, Castren M, Reul JM \& Holsboer F 1994 Heterodimerization between mineralocorticoid and glucocorticoid receptor: a new principle of glucocorticoid action in the CNS. Neuron 13 1457-1462. (doi:10.1016/0896-6273(94)90431-6)

Vize PD \& Smith HW 2004 A Homeric view of kidney evolution: A reprint of H.W. Smith's classic essay with a new introduction. Evolution of the kidney. 1943. Anatomical Record. Part A, Discoveries in Molecular, Cellular, and Evolutionary Biology 277 344-354. (doi:10.1002/ ar.a.20017)

Wambach G \& Higgins JR 1978 Antimineralocorticoid action of progesterone in the rat: correlation of the effect on electrolyte excretion and interaction with renal mineralocorticoid receptors. Endocrinology 102 1686-1693. (doi:10.1210/endo-102-6-1686)

Wang H, Bussy U, Chung-Davidson YW \& Li W 2016 Ultra-performance liquid chromatography tandem mass spectrometry for simultaneous determination of natural steroid hormones in sea lamprey (Petromyzon marinus) plasma and tissues. Journal of Chromatography B: Analytical Technologies in the Biomedical and Life Sciences 1009-1010 170-178. (doi:10.1016/j.jchromb.2015.12.030)

Williams SP \& Sigler PB 1998 Atomic structure of progesterone complexed with its receptor. Nature 393 392-396. (doi:10.1038/30775)

Woolston C 2013 'Living fossil' genome unlocked. Nature 496283. (doi:10.1038/496283a)

Yang J \& Young MJ 2009 The mineralocorticoid receptor and its coregulators. Journal of Molecular Endocrinology 43 53-64. (doi:10.1677/JME-09-0031)

Zhang J, Simisky J, Tsai FT \& Geller DS 2005 A critical role of helix 3-helix 5 interaction in steroid hormone receptor function. PNAS 102 2707-2712. (doi:10.1073/pnas.0409663102)

Received in final form 13 April 2017

Accepted 3 May 2017

Accepted Preprint Published Online 3 May 2017 http://joe.endocrinology-journals.org

DOI: 10.1530/JOE-16-0661
๑) 2017 Society for Endocrinology Printed in Great Britain
Published by Bioscientifica Ltd. 